\title{
The Long Journey Home, 96 Miles Up the Porcupine River / Ch'oodeenjik, Yukon
}

Bree Josie

Yukon College

Two summers ago, my husband and I would spend all our weekends up at his family's camp where the Porcupine River (Choodeenjik) meets the Driftwood River. We call it Driftwood-Troochoonjik Kaiik'it in Gwich'in. This is approximately 50 miles $(80 \mathrm{~km})$ upriver from our home community of Old Crow (Teechik). Old Crow is the northwestern-most community in Canada, only accessible by plane or boat.

We spent our days hunting for moose, caribou, and beaver; picking berries; fixing up our camp; hiking; fishing and checking the fish net; canoeing; gathering wood; and visiting with those who happened to be going by. Paul and I stayed in a canvas wall tent with a rusty wood stove.

Out at our Driftwood camp, Paul's family had built their own cabins (Figure 1). His Uncle Peter has a beautiful, old traditional log cabin, insulated with moss. His Aunt Jane has a more modern cabin built with plywood and insulation, his cousin Charles was just finishing up a modern log cabin for his family, and Paul's parents started a plywood cabin this year. Paul and I spent our summer camping in an old wall tent on a tent frame that we had fixed up and made our own (Figure 2). Our camp at Driftwood is completed with a kitchen shack, a meat cache, and an outhouse. Driftwood, as we call the camp, is a beautiful calm place. The Porcupine River (Choodeenjik) is quite still here and there isn't a lot of water traffic; few camps are near us and very few are further upriver (Figure 3). 
It was the last long weekend of the fall, and likely our last trip to Driftwood that year. We'd had an unlucky hunting season. The caribou were not near our community and we had damaged our boat trying to go up the shallow Crow River (Chyahnjik). With no caribou around, we decided to take the boat far up the Porcupine River, past Gopher Bluff (Tthaa Vibk'aa) to Porcupine Lake (Dinjik Goonli), which everyone fondly refers to as "Moose Country." The direct translation for Porcupine Lake in Gwich'in actually means "lots of moose." I had never been this far up the Porcupine River before. The furthest I had gone was to the Bell River (Chiiveenjik). I was excited for this adventure and even more excited at the prospect of moose meat.

It was Monday morning of the Labour Day weekend, and Paul's cousin, Aunt, and sister had gone back to Old Crow the day before, so left at camp were Paul, his father, a family friend, and me. The four of us woke up early in the morning, packed breakfast and thermoses of coffee, and headed on our journey upriver. We would make the journey to Porcupine Lake and hopefully get back to Old Crow late at night with a moose.

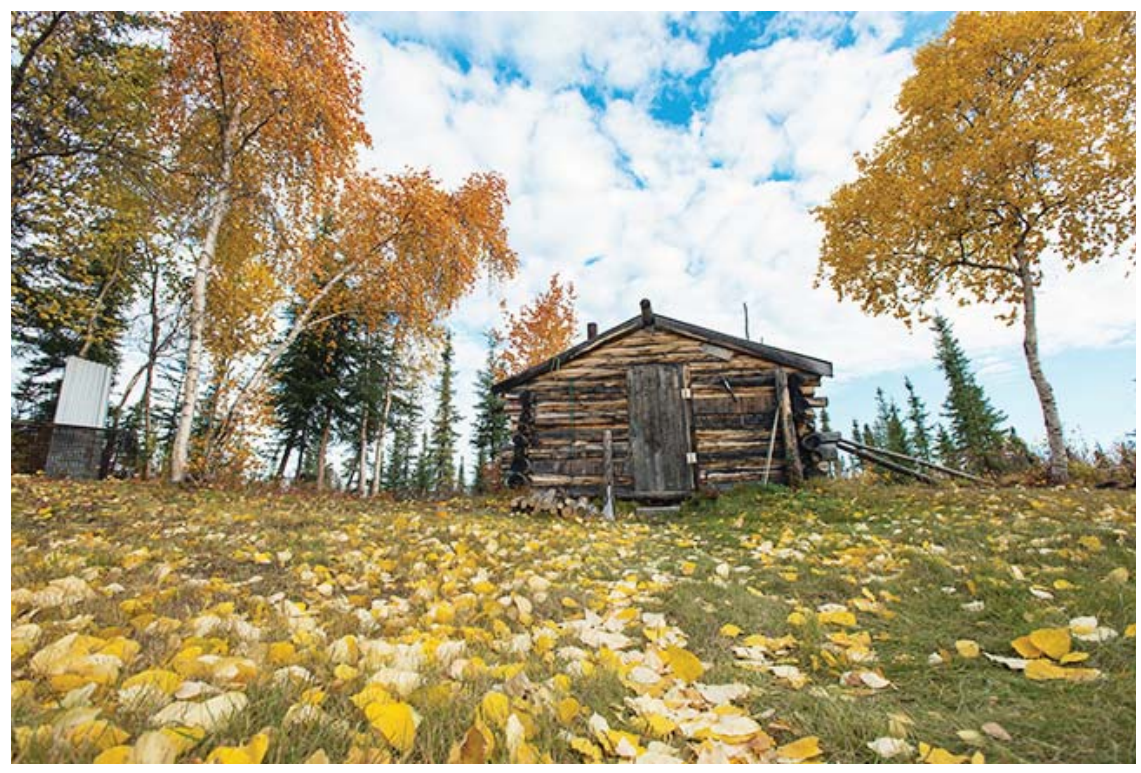

Figure I. Uncle Peter's cabin during fall harvest at the Josie family camp at Driftwood River. Photo Paul Josie 


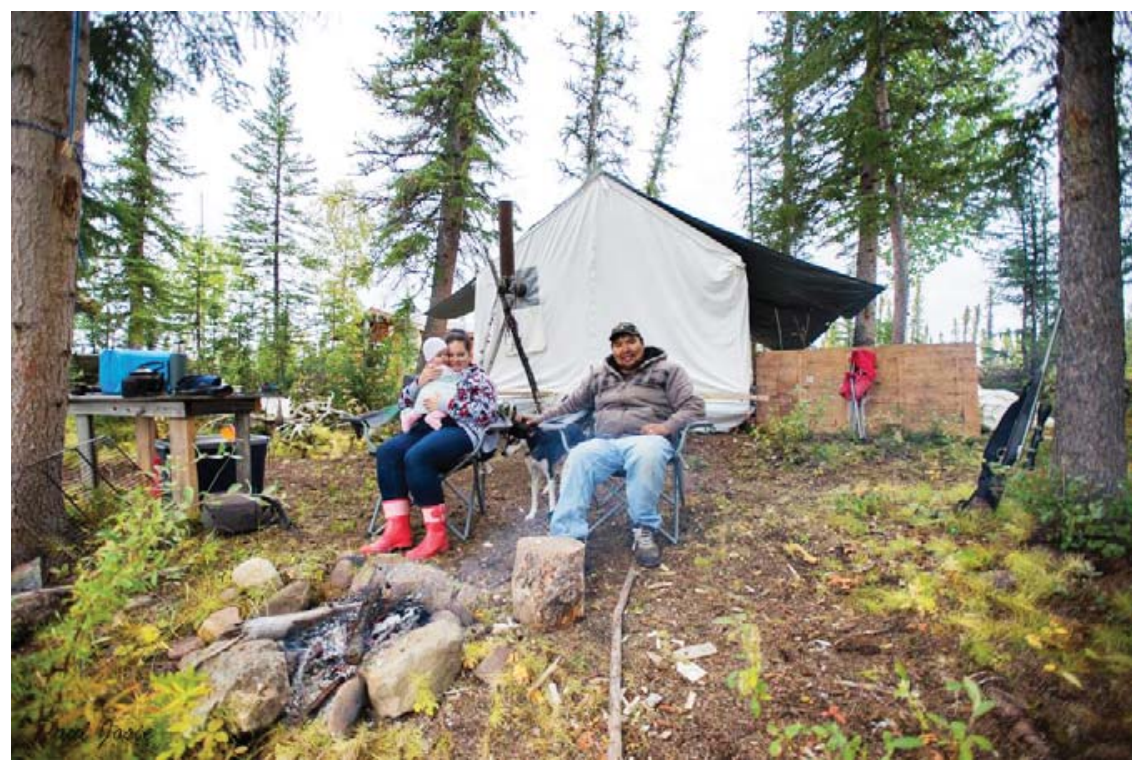

Figure 2. Paul and Bree Josie with their daughter Tl'yah Tr'an and sled dog, Aurora, in front of their wall tent at Driftwood. One year after their long journey home. Photo Paul Josie

We drove past Berry Creek (Jak Chyahnjik), a beautiful little creek where we had seen moose tracks and a bald eagle earlier in the summer. Just the day before, Paul had shot a beaver and we had brought it back from Berry Creek. We drove past Salmon cache (Ch'iitsii Ghe'), an old camp where the log structures still stand from when Gwich'in used to fish for and work with salmon. We stopped at the Bell River at Freddy Frost's camp (Freddy Frost Kaiik'it Chiiveechik Gwa'an) and stretched our legs and made a fire to warm up. We drove further and just as we were reaching Gopher Bluff, our boat motor started to make strange noises. We had to pull our boat over to the shore so we could get out and look at it.

We made a fire, opened some snacks, and explored the area while Paul's dad looked at the boat motor. We found an old camp where there had been a fire. Rusted tin cans on the ground; a rusted woodstove with half of it sunken into the ground. This camp was long forgotten. No one with us remembered a camp being in that area. We walked back to the boat where we received the worst news - the motor was shot. It could barely work. We weren't going to be going any further upriver, and we weren't sure how long it would take us to get back. We were about 96 miles $(155 \mathrm{~km})$ upriver and 
we had seen no one else on the river that day. Everyone had already made their way back to Old Crow.

So we packed our things back in the boat, pushed it into the river, and slowly, very, very slowly, made our way back to Driftwood. It had only taken us 2.5 hours to get from Driftwood camp to Gopher Bluff. That included a couple of stops along the way. But the boat with the broken motor was just putt-putting along slowly and we were basically floating with the current.

We stopped at every camp along the way as we went back. We stopped where the Porcupine River meets the Bell River. On one side of the Bell, there is Freddy Frost's cabin. We got out and walked around. Freddy hadn't been to his camp in a little while and a squirrel had decided to take over his cabin. It made a nice nest out of Freddy's emergency backpack. It was clear some moose and caribou had been camping in the area too, although we didn't see any. I walked around looking through the tall grass with the 270 on my back keeping an eye out for bears. My father-in-law and his friend were looking at the boat motor hoping to find a quick fix and my husband was collecting some wood for a small fire so we could warm up.

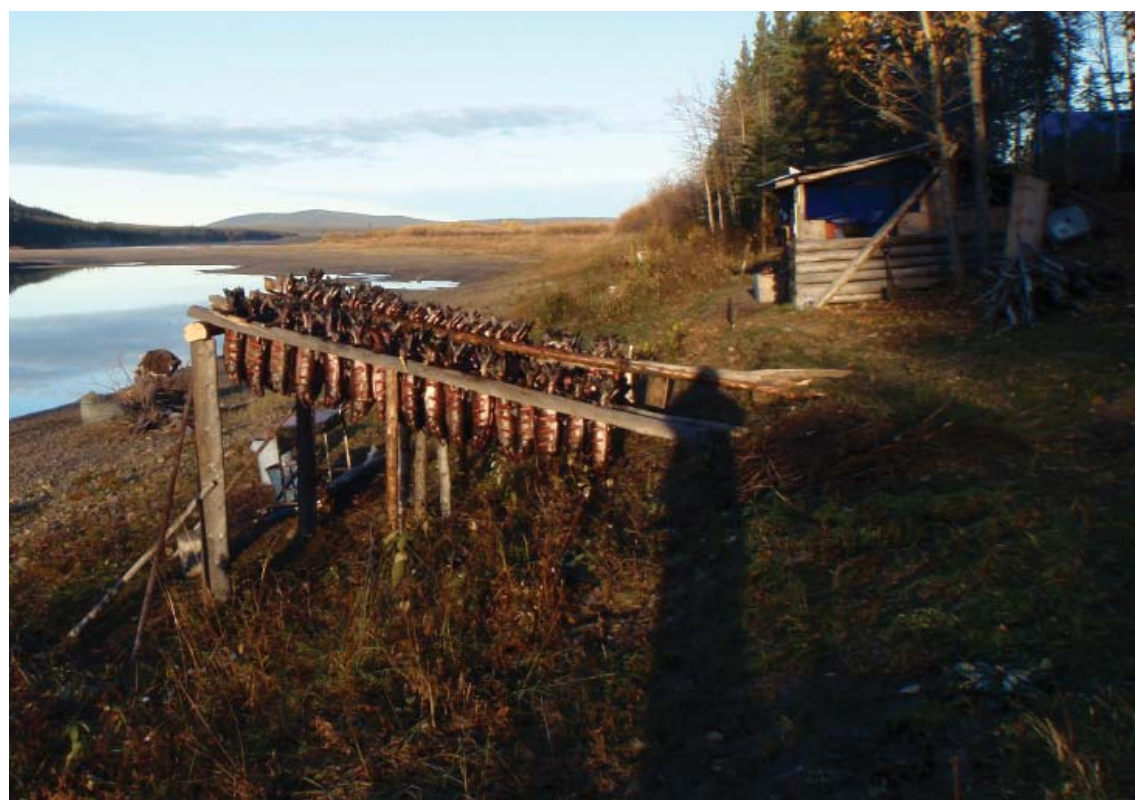

Figure 3. Chum salmon hanging to dry during the fall harvest at the Josie family camp at Driftwood River. Kitchen cache in the background. Photo Paul Josie 
We warmed up for a bit with a fire on the shore and headed downriver again towards Driftwood and Old Crow. Another couple of hours went by, and everyone was starting to get hungry. We had only packed breakfast and lunch with us and had expected to be back at the camp by dinner time. We had eaten all the food in our cooler except for a couple of apples. With our stomachs growling we didn't want to stop again. We just wanted to get back to Driftwood.

It took us eight hours to travel 30 miles $(48 \mathrm{~km})$ down the river. So, it was early evening when we arrived at our Driftwood camp. It was cold and starting to get dark. There was no way we would make it to Old Crow that night; we had only travelled about one-third of the distance. So, we decided to camp another night. The men went inside the cabins to make fires, and I started a fire in the kitchen cache and started to cook. I was starting to feel dizzy from hunger. We had a little food left, so I opened the bag labelled vadzaib chik (caribou ribs) and poured it into the pot of boiling water. My husband came over, looked in the pot, and said "that's not ribs," and he pulled it all out. It was vadzaih ch'its'ik (caribou bum guts). I had never cooked or eaten bum guts before in my life! Bum guts may not sound appetizing if you've never tried it, but those who have, love it.

Paul cut up the bum guts and fried them in a frying pan. I made some bannock with some Bisquick and UHT milk Auntie Jane had left behind. We also cooked some hot dogs we found in one of the coolers. We had basically used up everything in the food bins for dinner; I figured I could probably make some pancakes for breakfast with the Bisquick that was left, but we would have to start making our way home, or someone would need to come for us.

We woke up the next morning feeling quite cold-our fire had gone out. Paul and I joked about who was going to be the one to get out of bed and start the fire. He ended up jumping out of the bed, making a fire, and then crawling back in until the tent warmed up. We made coffee in our tent and then headed out to the kitchen cache. But as we opened the door to our tent we were greeted by a sheet of white snow. It was the first snowfall of the year. It had snowed six inches overnight and was still snowing. My eyes opened so wide. Not only was it going to take us sixteen to twenty hours to get home, it was going to be cold and snowy too. Our 
boat is a traditional wooden Gwich'in boat. It has low sides and is long, but it's completely open with no windshield or wall to protect you from the elements.

We went to the kitchen cache and had some pancakes for breakfast. We decided we would wait for the snow to stop and see if anyone would come and get us before we started making our way back. We tried the boat motor again to see if it was magically fixed. No luck. With the cold weather and snow, the boat motor wouldn't even start. We came to the realization that we would be paddling the rest of the way to Old Crow with very little food in our stomachs.

We packed up our gear. We had to make sure everything was waterproofed as we packed it in the boat. We knew that without a boat motor, we wouldn't be able to come back and pack up camp for the season, so we were packing up all our seasonal gear. We were not only going to have to paddle home, but we were paddling a boat with four people, two paddles, one dog, and a lot of gear. It was going to be heavy.

We bundled up in our warmest gear and then a boat showed up! We were happy for a tow. The boat helped us jumpstart our motor. We were travelling slowly again, but at least we weren't paddling. We made it a few bends down the river and our rescue boat passed us and went ahead. After a while we decided to give the motor a break and stop to warm up and have a snack. After our snack, the motor wouldn't start at all. Our rescue boat had left us and we were going to have to paddle.

We had three people, one oar, one paddle, and one pole. While my father-in-law used the pole to push us at the back, my husband used the oar on one side, and I paddled at the front on the other side. We had thought the faulty engine was slow. This was like crawling. We paddled around two bends. It was exhausting. We all kept switching positions so that none of us got sore on one side. The water was getting rough and pushing us to shore. We couldn't seem to keep the boat straight and we were frustrated, cold, and tired.

After two hours on our own, our rescue boat that had left us behind came back for us. We tied our boat to his. My father-in-law got in the tow boat, and my husband and I stayed in our little boat, to make sure it didn't tip or cut loose. As time went on, another rescue boat came along and my husband and I hopped on and made our way home. As the first signs of 
Old Crow appeared, smiles came across our faces. It was still daylight and we could grab a quick dinner from the store. We bought our rescuer some smokes as a thanks for the ride home. When our boat arrived, we pulled it from the water and sent the motor to Whitehorse. We would have to buy a new motor. It's times like this where you realize the remote nature of the community you live. We can't just call for help. You are out there and and need to rely on your friends and family to realize you are missing, and to come and look for you. Thank goodness for the kind-hearted Gwich'in, always looking out for one another and helping each other in times of need. Hai' Choo.

\section{Author}

Bree Josie is the community adult education coordinator at the Alice Frost Campus of Yukon College in Old Crow; Paul and Bree also run an Indigenous tourism business called Josie's Old Crow Adventures.

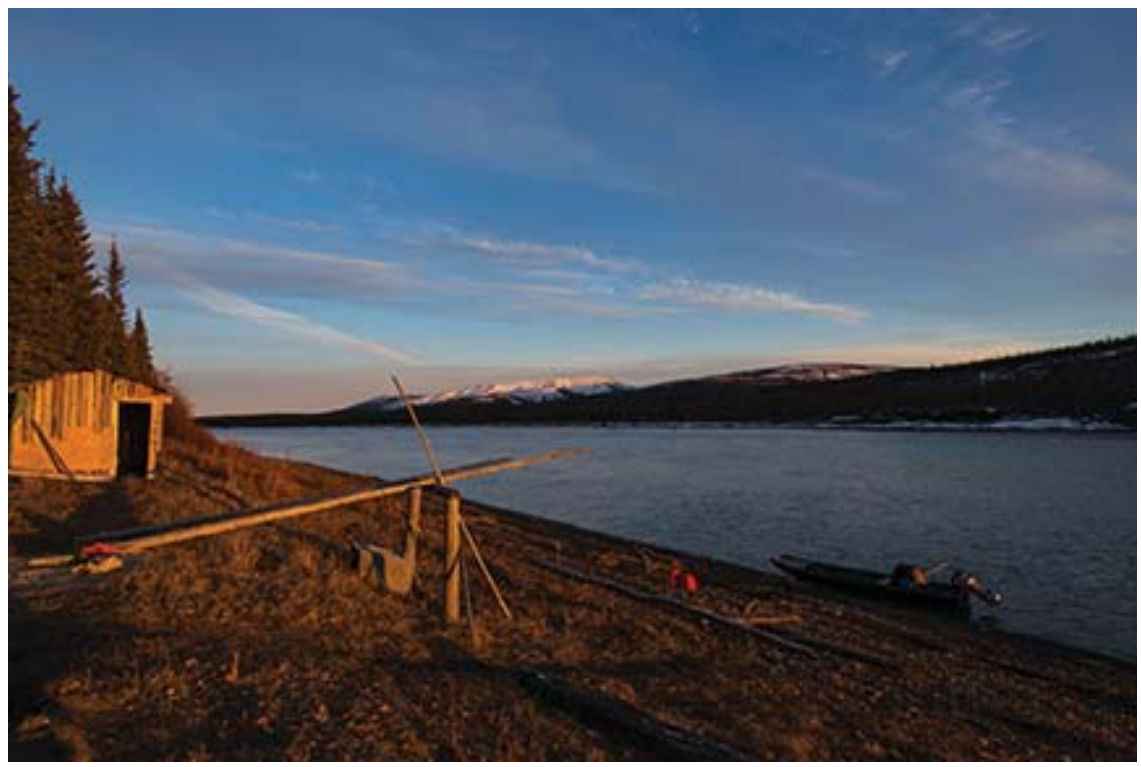

Figure 4.View from Driftwood Camp, Porcupine River. Photo Paul Josie. 